\title{
Spider Web Shape of Brass Catalytic Converter for Reducing Exhaust Gas Emission
}

\author{
Roro Heni Hendaryatia and Ali Mokhtarb \\ a,b Department of Mechanical Engineering, Faculty Of Engineering, University of Muhammadiyah Malang \\ JI. Raya Tlogomas No. 246, Malang, Indonesia \\ Telp. (0341) 464318-128 Fax. (0341) 460782 \\ e-mail: heni@umm.ac.id
}

\begin{abstract}
The rapid increase of the number of motor vehicles, especially motorcycles, makes serious problem caused by the pollution from gas emission of fossil fuel combustion. The problems related to human health and the erosion on ozone layer is credited to its gas emission. Several dangerous and toxic gasses such as Hydrocarbon (HC), Carbon Monoxide (CO), and Nitrogen Oxide $\left(\mathrm{NO}_{x}\right)$, Sulphur Dioxide (SO2), and Lead $(\mathrm{Pb})$ are emitted during IC engine operation.

To manage those dangerous gasses, catalytic converter which converts the gasses into more eco-friendly $\mathrm{CO}_{2} \mathrm{H}_{2} \mathrm{O}$ and $\mathrm{N}_{2}$ may be employed. In this research, a specially designed catalytic converter made from brass (CuZn) wire in the form of spider web pattern was fitted into exhaust system of a standard motorcycle. The performance of the converter for several engine rotation speeds was examined by measuring $\mathrm{CO}$ and $\mathrm{HC}$ of exhaust by using Gas Analyzer.

By comparing the exhaust of a standard exhaust system and modified exhaust system (fitted with converter), it can be concluded that the converter was able to decrease the exhaust emission gas. For HC content, the percentage of decrease was as much as 36,88 \% for converter fitted exhaust system compared to $61.12 \%$ for standard one. For CO content, the decrease percentage was $19.90 \%$ compared to $80.10 \%$ for standard one.
\end{abstract}

Keywords: spider web, brass, catalytic converter, gas emission

\section{INTRODUCTION}

Motor vehicles are the main transportation mode in the modern era. In line with the more efficient of automotive industries make the production volume of motor vehicle becomes higher with cheaper prices. This condition makes motor vehicles become more affordable to the most people. As the results, the pollution caused by exhaust gas emission becomes dangerously higher.

An internal combustion (IC) engine produce exhaust gas which typically comprised of Hydrocarbon ( $\mathrm{HC}$ ), Carbon Monoxide (CO), and Nitrogen Oxide (NOx), Sulphur Dioxide (SO2), and Lead ( $\mathrm{Pb})$. The most dangerous gas from the exhaust is $\mathrm{CO}$ as product of imperfect combustion which fatal to human when inhaled [1].

To reduce the risk of this dangerous gas, Environmental Sustainable Transportation (EST) program offered 12 programs or approaches to reduce the problem of air pollution, especially caused by transportation sector. One of the programs is to modify the exhaust system of motor vehicle by adding catalytic converter. The converter work is based on converting gas (such as $\mathrm{CO}$ ) by oxidation process to friendlier $\mathrm{CO}_{2}$ by chemical reaction in a medium which has catalyst property [2]. For reducing gas pollution from exhaust gas 
of IC engine, especially gasoline one, catalytic converter has also found its application [3]. Other techniques to reduce gas pollution in IC engine are modification of the IC Engine, fuels or combustion system, other than modification on the exhaust system [4].

Previous researches, showed that catalyst from Copper (Cu) and Brass (CuZn) could be employed to reduce the content of $\mathrm{CO}$ and $\mathrm{HC}$ from exhaust gas for range of engine rpm and number of catalyst cells. The several configuration of catalyst such as 12 (twelve) inline catalyst cells [5], perforated pipe of brass [6], and catalytic converter in shape of spider web made of Copper applied to Supra-X 125 motorcycle [7]. In other research, the effectiveness of substrate materials of catalyst, i.e. Brass, in reducing $\mathrm{NO}_{\mathrm{x}}$ for gasoline IC engine has been shown [8].

In this research, cheaper material (CuZn) was employed to filter the exhaust gas rather than using more expensive one such as Platinum (Pt) and Rhodium (Rh). CuZn is effective as converter as shown in above previous research. The solid CuZn in form of wire was employed as catalyst because its availability and versatility to employ for different shape. The spider web shape was employed with the consideration of good strength and filtering capability of the shape.

\section{Methodology}

Specially designed catalytic converter as shown in Figure 2.1 was examined for its effectiveness in reducing dangerous gasses in exhaust of IC engine. The casing was designed in accordance with the shape of standard exhaust system of motorcycle. Also the inner diameter and thickness of casing wall followed the standard to maintain the functions of exhaust system as effective as standard one to dissipate heat and flow the exhaust.

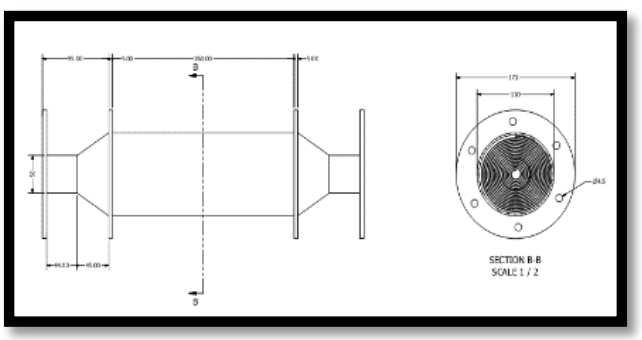

(a)

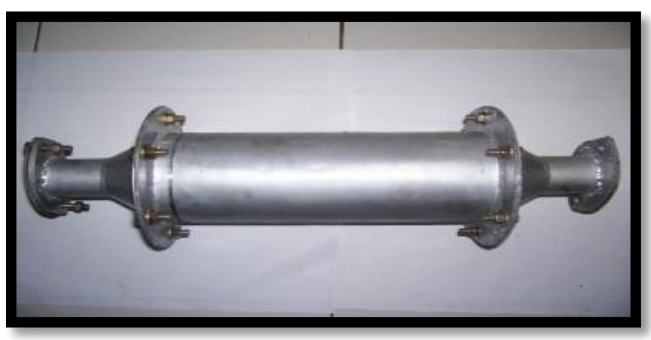

(b)

Figure 2.1 Casing of catalytic converter, a. Drawing, b. Actual.

The catalytic converter was assembled from Brass (CuZn) wire with diameter of 0.8 $\mathrm{mm}$ and Copper $(\mathrm{Cu})$ wire with diameter of $0.4 \mathrm{~mm}$ and takes the shape of spider web with 13 row of converter as depicted in Figure 2.2.

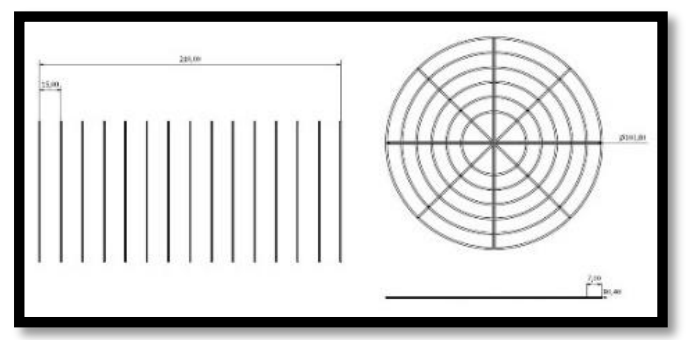

(a)

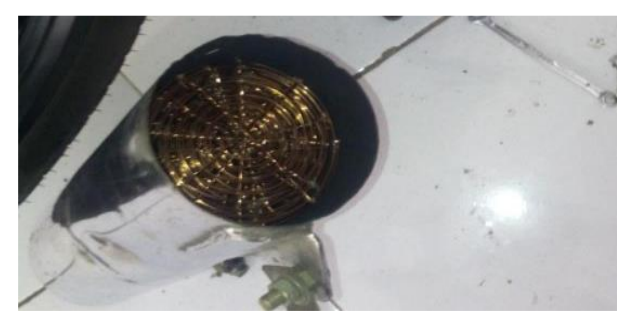

(b)

Figure 2.2 Design of catalytic converter, a. Drawing, b. Actual. 
The research has been carried out by employing experimental methods. The catalytic converter then was installed in motorcycle exhaust system. The contents of HC and $\mathrm{CO}$ were measured using Gas Analyser for standard exhaust system and catalytic converter installed one. The variables for the experiment were given in Table 2.1 below. The fuel for the research was Pertalite $\mathrm{TM}^{\mathrm{M}}$, and the research was executed by varying the engine rpm to several values. Variable response for the research was the content of exhaust gasses as measured by Gas Analyser. The flowchart of the research was given in Figure 2.3.

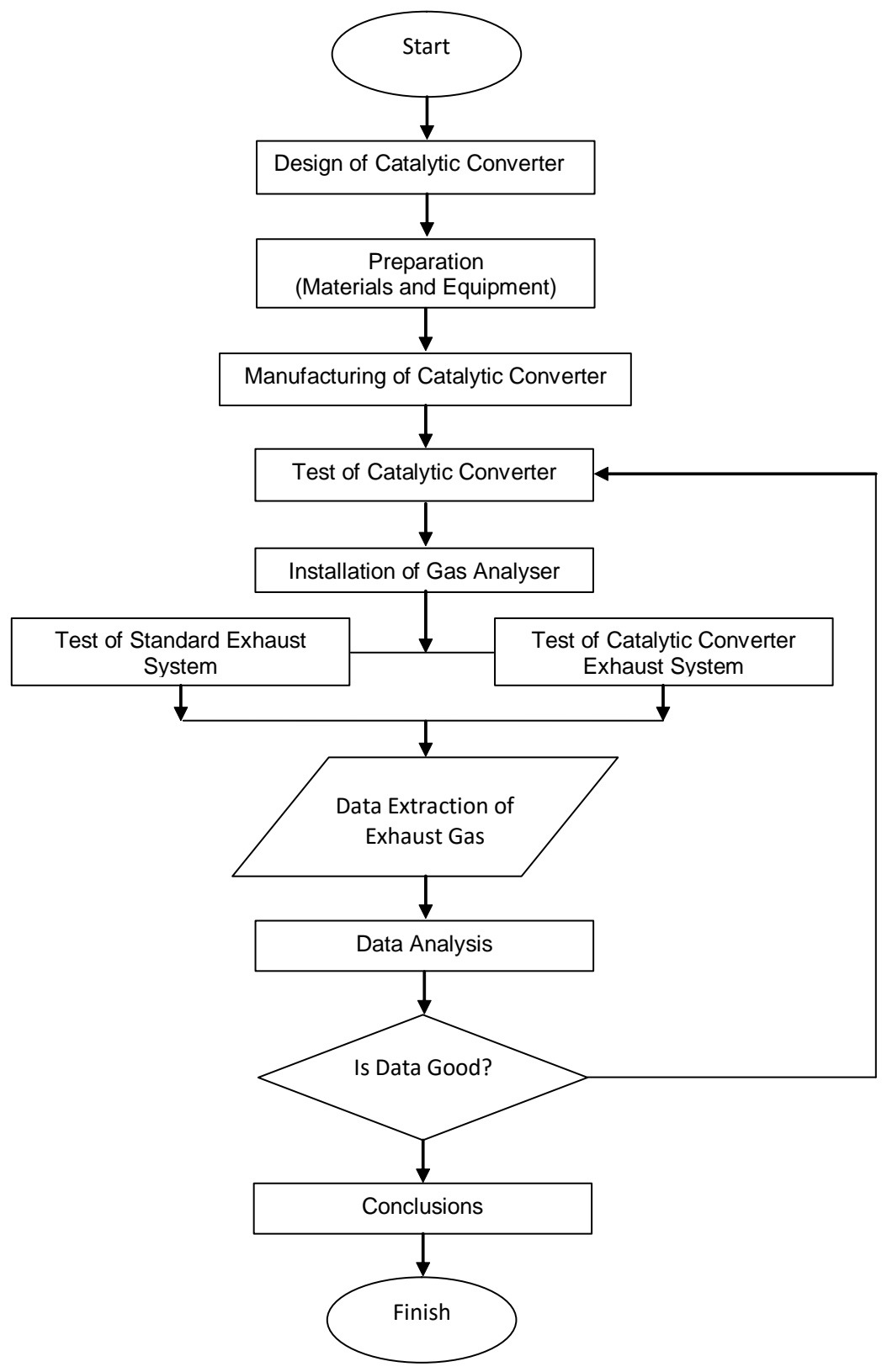

Figure 2.3 Flowchart of the experiment of catalytic converter

To execute the research, the experimental design was given in Table 2.1 below. It compared two exhaust systems, the standard one and catalytic converter installed one. The fuel for the experiment was Pertalite ${ }^{\mathrm{TM}}$ from Pertamina with 5 replications per cell. 


\begin{tabular}{|c|c|c|c|c|c|}
\hline & \multicolumn{4}{|c|}{ Table 2.1 Variables for the experiment } & \multirow[b]{3}{*}{3500} \\
\hline \multirow[t]{2}{*}{ Exhaust System } & \multirow[t]{2}{*}{ Fuel } & \multicolumn{3}{|c|}{ Engine rpm } & \\
\hline & & 1500 & 2000 & 2500 & \\
\hline Standard & Pertalite & $\mathrm{D}_{111}$ & $\mathrm{D}_{121}$ & $D_{131}$ & $\mathrm{D}_{141}$ \\
\hline & & $D_{112}$ & $D_{122}$ & $D_{132}$ & $D_{142}$ \\
\hline & & $D_{113}$ & $\mathrm{D}_{123}$ & $\mathrm{D}_{133}$ & $D_{143}$ \\
\hline & & $\mathrm{D}_{114}$ & $D_{124}$ & $D_{134}$ & $D_{144}$ \\
\hline & & $D_{115}$ & $\mathrm{D}_{125}$ & $\mathrm{D}_{135}$ & $\mathrm{D}_{145}$ \\
\hline Spider web & Pertalite & $D_{211}$ & $D_{221}$ & $D_{231}$ & $D_{241}$ \\
\hline converter & & $D_{212}$ & $D_{222}$ & $D_{232}$ & $D_{242}$ \\
\hline & & $D_{213}$ & $D_{223}$ & $D_{233}$ & $D_{243}$ \\
\hline & & $D_{214}$ & $D_{224}$ & $D_{234}$ & $D_{244}$ \\
\hline & & $D_{215}$ & $D_{225}$ & $D_{235}$ & $D_{245}$ \\
\hline
\end{tabular}

The experimental runs were depicted in Figure 2.3 below and were taken on 9 January 2017 in Automotive Engineering Laboratory, State University of Malang.

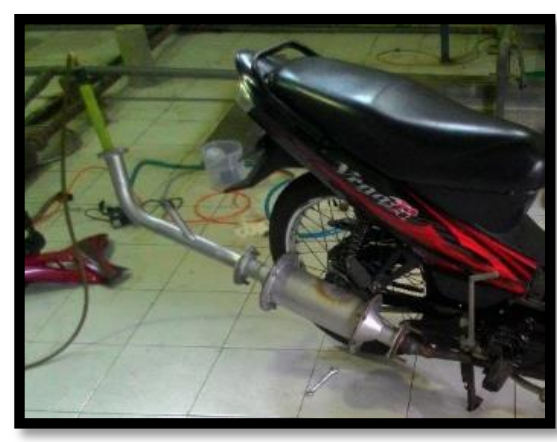

(a)

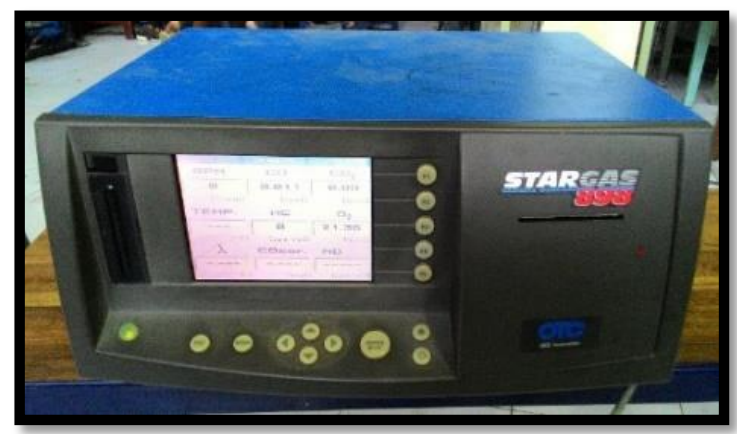

(b)

Figure 2.3 Experimental runs, a. Test stand, b. Gas analyser.

The data measured for the experiment were content of $\mathrm{HC}, \mathrm{CO}, \mathrm{CO}_{2}$, and $\mathrm{O}_{2}$.

\section{Result ANd Discussion}

The data of exhaust system content was depicted in Table 3.1 and Table 3.2 below.

Table 3.1 Content of exhaust gas for standard exhaust system

\begin{tabular}{ccrrrr}
\hline Engine rpm & Data & $\mathbf{H C}(\mathbf{p p m})$ & $\mathbf{C O}(\%)$ & $\mathbf{C O}_{2}(\%)$ & $\mathbf{O}_{2}(\%)$ \\
\hline 1500 & average & 214.4 & 2.978 & 3.66 & 14.84 \\
2000 & average & 228.0 & 2.874 & 3.40 & 15.52 \\
2500 & average & 251.8 & 2.430 & 2.86 & 16.28 \\
3500 & average & 260.6 & 3.330 & 3.68 & 14.22 \\
\hline \hline
\end{tabular}

JEMMME | Journal of Energy, Mechanical, Material, and Manufacturing Engineering 


\begin{tabular}{|c|c|c|c|c|c|}
\hline Engine rpm & Data & HC (ppm) & CO (\%) & $\mathrm{CO}_{2}(\%)$ & $\mathrm{O}_{2}(\%)$ \\
\hline 1500 & average & 162.8 & 2.254 & 3.34 & 16.32 \\
\hline 2000 & average & 263.2 & 1.448 & 1.94 & 18.12 \\
\hline 2500 & average & 260.6 & 2.192 & 2.58 & 16.06 \\
\hline 3500 & average & 265.8 & 2.950 & 3.28 & 14.90 \\
\hline
\end{tabular}

After data on the contents of gasses have been acquired, the next step was to count the percentage of emission and percentage of emission reduction according to the Equation 1 and Equation 2.

$$
\text { Percentage of emission }=\frac{\text { emission average with catalyst }}{\text { emission average with catalyst }} \times 100 \%
$$

and

$$
\text { Percentage of emission reduction }=100-\text { Percentage of emission }
$$

The results were presented in Table 3.3, Table 3.4, and Table 3.5 below.

Table 3.3 Percentage of emission

\begin{tabular}{lrrrr}
\hline Exhaust System & $\mathbf{H C}(\mathbf{p p m})$ & $\mathbf{C O}(\%)$ & $\mathbf{C O}_{2}(\%)$ & $\mathbf{O}_{2}(\%)$ \\
\hline Standard & 238.7 & 2.903 & 3.400 & 15.215 \\
Catalytic Converter & 238.1 & 2.211 & 2.785 & 16.350 \\
Value & $\mathbf{9 9 . 7 5}$ & $\mathbf{7 6 . 1 6}$ & $\mathbf{8 1 . 9 1}$ & $\mathbf{1 0 7 . 0 0}$ \\
\hline \multicolumn{5}{c}{} \\
\hline \multicolumn{5}{c}{ Table 3.4 Percentage of emission reduction } \\
\hline Value & $\mathbf{H C}(\mathbf{p p m})$ & $\mathbf{C O}(\%)$ & $\mathbf{C O}_{2}(\%)$ & $\mathbf{O}_{2}(\%)$ \\
\hline
\end{tabular}

Table 3.5 Comparison of percentage of emission reduction

\begin{tabular}{lrrr}
\hline \multicolumn{1}{c}{ Materials } & HC (ppm) & CO (\%) \\
\hline Brass & 0.25 & 23.837 \\
\hline Copper & 18.24 & 38.696 \\
\hline
\end{tabular}

\section{Conclusion}

From the research, the relationship between $\mathrm{HC}$ and engine rpm was depicted in Graphic 4.1.

\section{HC vs Variabel putaran}

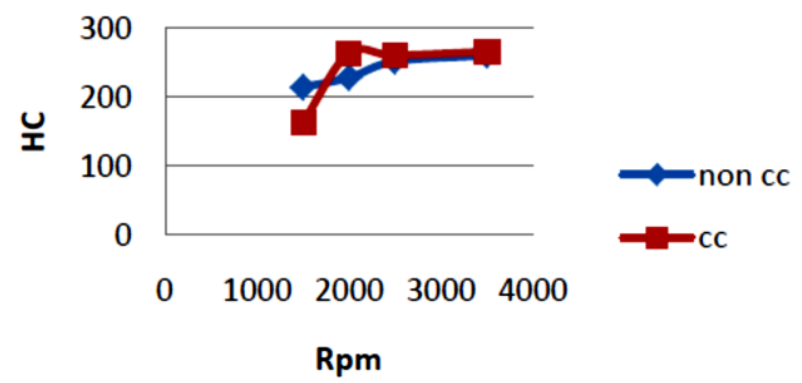

Graphic 4.1 Relationship between emission of HC and engine rpm 
Reduction in $\mathrm{HC}$ emission for catalytic converter could be considered insignificant since only $0.25 \mathrm{ppm}$ of reduction was achieved. This trend may be caused by the mechanism of combustion which unable to combust all available fuel (imperfect combustion) in combustion chamber or maybe misfire. Another cause may be there was failure/trouble in firing system such as bad plug or its wire, early combustion or low compression pressure.

Also, from Graphic 4.1 it was shown that reduction of $\mathrm{HC}$ emission is not consistent since for $1500 \mathrm{rpm}$ it decreased significantly from $214.4 \mathrm{ppm}$ for standard exhaust system to $162.6 \mathrm{ppm}$ for catalytic converter installed exhaust system. But, in higher rpm the trend of $\mathrm{HC}$ emission was always above the standard emission. In general, the catalytic converter converts $\mathrm{HC}$ into water $(\mathrm{H} 2 \mathrm{O})$ and carbon dioxide $(\mathrm{CO} 2)$ thru oxidation process as follows:

$$
\mathrm{CH}+\mathrm{C}_{2} \rightarrow \mathrm{H}_{2} \mathrm{O}+\mathrm{CO}_{2}
$$

The surface contact of the catalyst gives activation energy to oxidate $\mathrm{HC}$ (hydrocarbon) into $\mathrm{H}_{2} \mathrm{O}$ (water) and $\mathrm{CO}_{2}$ so that reduction of $\mathrm{CH}$ is achieved.

In this research, even though the content of $\mathrm{CO} 2$ of catalytic converter installed exhaust system is always lower than standard one but the measurement of $\mathrm{HC}$ showed the contradictions. It is an interesting one to be examined more in the next experiment.

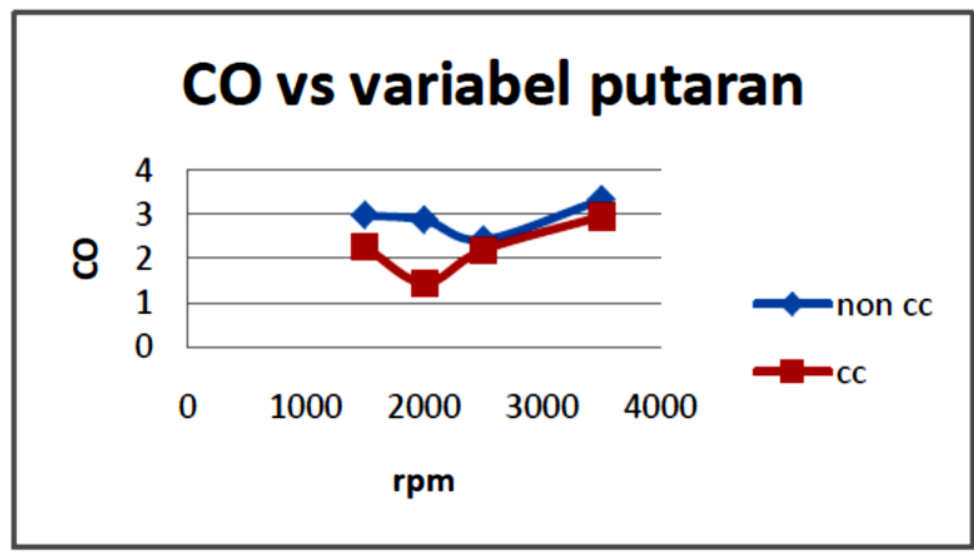

Graphic 4.2 Relationship between emission of $\mathrm{CO}$ and engine rpm

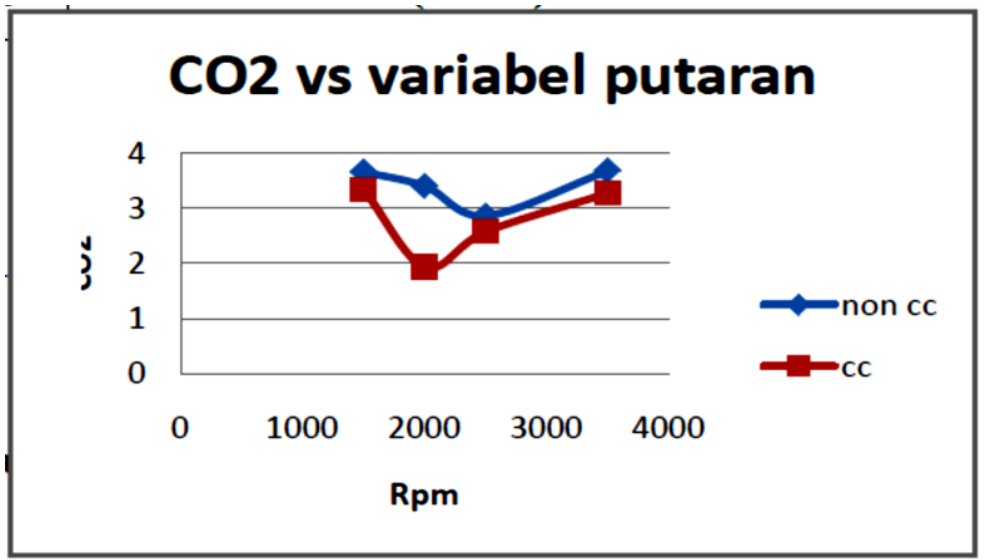

Graphic 4.3 Relationship between emission of $\mathrm{CO}_{2}$ and engine rpm 
The reduction of $\mathrm{CO}$ emission could be considered good with percentage of reduction reached $23.837 \%$. The mechanism of $\mathrm{CO}$ reduction is as follows:

$$
2 \mathrm{CO}+\mathrm{O}_{2} \rightarrow 2 \mathrm{CO}_{2}
$$

The trend of reduction in $\mathrm{CO}$ was not following the smooth with lowest emission on $2000 \mathrm{rpm}$. This trend may be caused by non-homogenous mixture of fuel and air in IC engine test bed.

The reduction of $\mathrm{CO}_{2}$ emission could be considered good with percentage of reduction reached $18.088 \%$. The result also shows that the catalytic converter was able to convert $\mathrm{CO}$ into $\mathrm{CO}_{2}$ so that the emission of $\mathrm{CO}_{2}$ was better for every rpm.

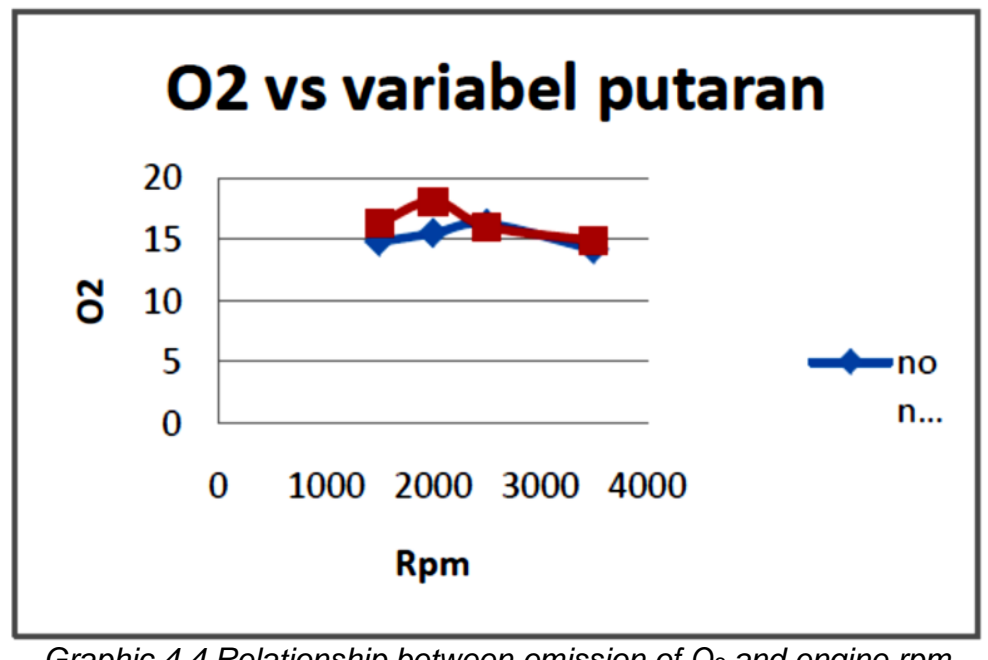

The reduction of $\mathrm{O}_{2}$ emission could be considered well with percentage of reduction reached $-7.0 \%$ which means there was increase of $\mathrm{O}_{2}$ emission. This result was contrary to the theory of catalytic converter in which the oxidation process of $\mathrm{HC}$ (Equation 3 ) and $\mathrm{CO}$ (Equation 4) and there was a big possibility that the casing of exhaust system supply more $\mathrm{O}_{2}$ thru some unsealed surface (leaked). In general, the research has proven that the designed catalytic converter was able to reduce the dangerous gas such as $\mathrm{CO}$ in all rpm and to some extent the content of $\mathrm{HC}$ (on $1500 \mathrm{rpm}$ ).

\section{REFERENCES}

[1] Wardhana, W.A. Dampak Pencemaran Lingkungan. Yogyakarta: Penerbit Andi. 2004.

[2] Dowden, D.A. et.al. Catalytic Hand Book. New York: Verlag, Inc. 1970.

[3] Heisler, H. Advanced Engine Technology. London: Hodder Headline Group. 1995.

[4] Mathur, S.L. Internal Combustion Engine. Second Edition. New York: McGraw-Hill Book Company, Inc. 1975.

[5] Refkiandi, R. and Mokhtar, A. Catalytic Converter Jenis Tembaga dan Kuningan Berbentuk Plat Sejajar Susunan 12 Sel. Final Project. Malang: Undergraduate Program of Department of Mechanical Engineering UMM 2010.

[6] Mokhtar, A. Catalytic Converter Jenis Katalis Pipa Kuningan Berlubang untuk Mengurangi Emisi Kendaraan Bermotor. Laporan Penelitian, Universitas Muhammadiyah Malang. 2012. 
[7] Hafid, L. Catalytic Converter Berbahan Tembaga Berbentuk Sarang Laba-laba Pada Knalpot Supra-X 125 Untuk Mengurangi Emisi Gas Buang. Final Project. Malang: Undergraduate Program of Department of Mechanical Engineering UMM. 2016.

[8] Irawan, B. and Subri, M. Efektivitas Katalis Material Substract Paduan CuZn (Kuningan) Dalam Mereduksi Emisi gas Karbon Monoksida Motor Bensin. Traksi. 2005; 3 ( 2). 